\title{
PENGARUH INTELLECTUAL CAPITAL DAN CORPORATE GOVERNANCE TERHADAP NILAI PERUSAHAAN DENGAN PROFITABILITAS SEBAGAI VARIABEL MODERASI
}

\author{
Anisa Hediyanti Muasiri ${ }^{1)}$, Erna Sulistyowati ${ }^{2}$ \\ ${ }^{1}$ Fakultas Ekonomi dan Bisnis, UPN "Veteran" Jawa Timur \\ email: 17013010175@student.upnjatim.ac.id \\ ${ }^{2}$ Fakultas Ekonomi dan Bisnis, UPN "Veteran" Jawa Timur \\ email: ernas.ak@upnjatim.ac.id
}

\begin{abstract}
This study aims to test the influence of intellectual capital and corporate governance on firm value with profitability as a moderating variable. The population of this study is banking companies listed on IDX during 2015 - 2019 amounted to 45 companies. Sampling techniques using purposive sampling so that research samples obtained as many as 15 companies. The research data used is secondary data obtained from the annual report and GCG report of banking companies listed on IDX during 2015 - 2019. This study uses structural equation modeling data analysis technique - partial least square (SEM-PLS) with WarpPLS 7.0 software. The result of this study shows that: (1) Intellectual capital positively and significantly affects the firm value, (2) Corporate governance has no effect on the firm value, (3) Profitability can moderate the influence of intellectual capital on the firm value, (4) Profitability can't moderate the influence of corporate governance on the firm value.
\end{abstract}

Keywords: Intellectual Capital, Corporate Governance, Firm Value, Profitability

\section{PENDAHULUAN}

Fenomena globalisasi yang dimulai pada awal abad ke - 20 mengakibatkan perekonomian dunia semakin berkembang begitu pesat ditandai dengan kemajuan di bidang ilmu pengetahuan, teknologi informasi dan semakin ketatnya persaingan bisnis dengan adanya inovasi - inovasi baru yang terus bermunculan. Revolusi industri 4.0 tidak dapat dihindari lagi.seiring dengan perubahan dan kemajuan perekonomian dunia serta semakin terbukanya masyarakat modern dengan ilmu pengetahuan dan teknologi informasi, mendorong perusahaan semakin berfokus pada pentingnya knowledge assets sebagai bentuk aset tidak berwujud atau intangible assets yang menjadi sumber baru dari kekuatan kinerja keuangan dan keunggulan kompetitif yang patut dibanggakan oleh perusahaan (Nugroho \& Gudono, 2018).

Hal ini ditandai dengan pergeseran strategi bisnis perusahaan dari physical-based economy menjadi knowledge-based economy, sehingga karakteristik utama perusahaan berubah menjadi perusahaan berbasis ilmu pengetahuan dengan penerapan manajemen pengetahuan atau knowledge management (Soewarno \& Tjahjadi, 2020).

Penerapan modal berbasis ilmu pengetahuan dan teknologi dalam suatu perusahaan akan meningkatkan efisiensi dan efektifitas penggunaan sumber daya yang lainnya sehingga dapat menciptakan nilai tambah (value added) dan keunggulan kompetitif bagi perusahaan (Fardiansyah \& Faisal, 2020).

Nilai tambah (value added) tersebut berupa adanya ilmu pengetahuan, teknologi 
informasi, inovasi, perkembangan karyawan dan hubungan yang baik dengan para konsumen yang kemudian diistilahkan sebagai intellectual capital. Hal ini mebawa peningkatan perhatian terhadap intellectual capital. Intellectual capital merupakan jumlah yang dihasilkan oleh tiga elemen utama yaitu capital employed, human capital dan structural capital. Ketiga elemen tersebut berkaitan dengan ilmu pengetahuan dan teknologi yang dapat meciptakan nilai tambah (value added) bagi perusahaan dan merupakan suatu keunggulan kompetitif bagi perusahaan (Sayyidah \& Saifi, 2017).

Pengakuan dan pelaporan intellectual capital akan mendorong meningkatnya nilai perusahaan. Semakin tinggi nilai intellectual capital menunjukkan bahwa semakin baik manajemen dalam mengelola perusahaan, sehingga menjadi dalah satu faktor bagi investor untuk memberikan nilai pasar yang tinggi bagi perusahaan (Yulandari \& Gunawan, 2019).

Selain adanya fenomena intellectual capital, di tengah pesatnya perkembangan bisnis global, setiap perusahaan berusaha untuk selalu dinamis mengikuti keinginan pasar. Kompetisi bisnis yang semakin ketat mendorong perusahaan untuk bersaing mmendapatkan citra yang baik dari para pemangku kepentingan. Selain mengoptimalkan pemanfaatan intellectual capital, perusahaan diharapkan mampu berjalan seimbang dengan memperhatikan penerapan corporate governance atau tata kelola perusahaan. Corporate governance menjadi salah satu kunci kesuksesan perusahaan dalam meningkatkan efisiensi dan efektivitas pertumbuhan bisnis, meningkatkan kepercayaan investor dan melindungi kepentingan investor (Suhadak et al., 2019).

Corporate governance diharapkan dapat memberikan dampak pada peningkatan kinerja perusahaan. Kinerja perusahaan yang meningkat akan dapat menarik minat investor untuk berinvestasi sehingga memicu peningkatan nilai perusahaan (Rochmawati et al., 2020).

Nilai perusahaan merupakan persepsi investor terhadap tingkat keberhasilan perusahaan dalam mengelola sumber daya yang dimiliki yang tercermin dari harga saham perusahaan di pasar modal. Pasar modal memiliki peran penting bagi perekonomian suatu negara karena menjadi sarana untuk mendapatkan dana dari masyarakat pemodal atau investor (Arifardhani, 2020:8).

Kondisi pasar modal Indonesia di Bursa Efek Indonesia (BEI) terus berkembang dengan bertambahnya jumlah perusahaan yang melakukan perdagangan saham dan semakin meningkatnya kesadaran masyarakat untuk berinvestasi saham di pasar modal.

Salah satu sektor perusahaan yang terdaftar di Bursa Efek Indonesia (BEI) adalah perusahaan perbankan. Saham perusahaan perbankan menjadi salah satu saham dengan kapitalisasi terbesar di Bursa Efek Indonesia (www.idx.co.id). Hal ini dikarenakan perusahaan perbankan merupakan sektor yang strategis bagi para investor untuk melakukan investasi karena kinerja perusahaan perbankan akan selalu diawasi dan dijamin oleh pemerintah melalui BI dan OJK sehingga perusahaan perbankan senantiasa menjaga tingkat kesehatan bank dan kinerja perusahaan sesuai dengan peraturan yang dikeluarkan oleh regulator (Purnama \& Rikumahu, 2020).

Pemilihan perusahaan perbankan sebagai subjek dalam penelitian ini karena industri perbankan di Indonesia menghadapi tantangan berat dari persaingan global dengan munculnya digitalisasi perbankan dan merupakan salah satu sektor yang paling intensif menggunakan intellectual capital (Soewarno \& Tjahjadi, 2020). Selain itu penerapan konsep corporate governance pada perusahaan perbankan sangat ketat karena diawasi oleh OJK dan BI (Purnama \& Rikumahu, 2020). 
Berdasarkan latar belakang masalah yang telah diuraikan di atas maka penulis tertarik untuk melakukan penelitian dengan judul "Pengaruh Intellectual Capital dan Corporate Governance Terhadap Nilai Perusahaan dengan Profitabilitas sebagai Variabel Moderasi"

Berdasarkan latar belakang yang telah diuraikan di atas, maka akan dilakukan penelitian mengenai permasalahan tersebut. Rumusan masalah yang akan dibahas dalam penelitian ini adalah:
1. Apakah
Intellectual
Capital
berpengaruh
terhadap
Nilai
Perusahaan?

2. Apakah Corporate Governance berpengaruh terhadap Nilai Perusahaan?

3. Apakah Intellectual Capital berpengaruh terhadap Nilai Perusahaan yang dimoderasi dengan Profitabilitas?

4. Apakah Corporate Governance berpengaruh terhadap Nilai Perusahaan yang dimoderasi dengan Profitabilitas?

\section{Resource-Based Theory}

Resource-Based

Theory

$(R B T)$

merupakan kerangka kerja yang menekankan pada pemahaman sumber sumber keunggulan kompetitif berkelanjutan yang dikendali oleh perusahaan dan memungkinkan perusahaan untuk menerapkan strategi guna meningkatkan efisiensi dan efektivitas kinerja perusahaan. Sumber daya dalam keunggulan kompetitif berkelanjutan harus bernilai (valuable resources), langka (rare resources), tidak dapat ditiru (imperfectly imitable resources) dan tidak memiliki sumber daya pengganti (non-substitutability resources) (Barney, 1991)

Menurut Ulum (2017:23) ResourceBased Theory (RBT) menunjukkan bahwa perusahaan memiliki sumber daya yang mampu menjadikan perusahaan memiliki keunggulan kompetitif dan memiliki kinerja jangka panjang yang baik. Sumber daya yang dimiliki perusahaan harus diorganisir, dikombinasikan dan dimanfaatkan secara tepat sehingga terciptalah keunggulan kompetitif serta mengarahkan perusahaan untuk dapat meningkatkan produktivitas dan kinerja perusahaan secara keseluruhan (Davis \& Simpson, 2017).

Keunggulan kompetitif yang dimiliki perusahaan dapat meningkatkan daya tarik investor untuk melakukan investasi di perusahaan. Peningkatan jumlah investor ini dapat meningkatkan harga saham perusahaan dan merupakan indikasi bahwa pasar memberikan nilai yang baik terhadap perusahaan (Lestari \& Satyawan, 2019).

\section{Signaling Theory}

Menurut Spence (1973) Signaling Theory berkaitan dengan dua pihak yakni manajemen yang berperan sebagai pihak yang menerima sinyal dan pihak luar seperti investor yang berperan sebagai pihak yang menerima sinyal. Melalui sinyal ini, pihak manajemen berusaha memberikan informasi yang dapat digunakan oleh pihak investor dalam pengambilan keputusan untuk berinvestasi sesuai dengan pemahamannya terhadap sinyal yang diberikan.

Signaling theory berfokus pada pentingnya informasi yang dikeluarkan perusahaan terhadap keputusan investasi pihak - pihak di luar perusahaan. Salah satu informasi yang dikeluarkan adalah laporan tahunan berupa informasi akuntansi dalam laporan keuangan dan informasi nonakuntansi yang tidak berkaitan dengan laporan keuangan (Ulum, 2017:33).

Signaling theory dapat mempengaruhi nilai perusahaan karena teori ini memberikan informasi mengenai kondisi perusahaan melalui laporan tahunan. Hubungan signaling theory dengan nilai perusahaan menjelaskan bahwa ketika perusahaan mempublikasikan laporan tahunan terkait kondisi perusahaan meliputi laba perusahaan dan nilai perusahaan yang tercermin pada harga saham perusahaan yang akan menarik minat calon 
investor untuk membuat keputusan investasi (Hidayati \& Retnani, 2020).

\section{Stakeholder Theory}

Menurut Deegan (2004) stakeholder theory menekankan akuntabilitas perusahaan jauh melebihi kinerja keuangan atau ekonomi sederhana. Perusahaan akan mengungkapkan informasi tentang kinerja lingkungan, sosial dan intelektual secara sukarela melebihi permintaan wajibnya untuk memenuhi ekspektasi para stakeholder. Teori menyatakan bahwa seluruh stakeholder memiliki hak untuk disediakan informasi tentang aktivitas perusahaan.

Stakeholder theory menyatakan bahwa perusahaan bukanlah entitas yang hanya beroperasi untuk kepentingan perusahaan semata, namun juga harus memberikan manfaat kepada seluruh stakeholder (Ghozali dan Chariri dalam Devi, 2017). Tujuan utama dari teori ini adalah untuk mebantu manajer perusahaan mengerti lingkungan para pemangku kepentingan dan mengelola perusahaan dengan lebih efektif di antara keberadaan hubungan - hubungan di lingkungan perusahaan sehingga dapat meminimalkan kerugian yang dapat dialami oleh para pemangku kepentingan (Ulum, 2017:35).

\section{Agency Theory}

Jensen \& Meckling (1976) menyatakan bahwa Agency Theory atau hubungan keagenan merupakan sebuah kontrak atau perjanjian antara manajer perusahaan sebagai agent dan investor sebagai principal yang terkadang menimbulkan asimetri informasi dari manajer kepada investor sehingga dapat menimbulkan biaya keagenan (agency cost).

Agency theory menjelaskan hubungan agensi yang terjadi karena tanggung jawab yang sesuai dengan kepentingan principal dimana principal sebagai pemilik modal tidak memiliki kemampuan dan keterampilan dalam mengelola perusahaan, sehingga memberikan kewenangan kepada agent untuk menjalankan aktivitas operasi perusahaan dan mengambil keputusan dalam setiap permasalahan yang berkaitan dengan operasional perusahaan yang telah tertuang dalam perjanjian yang telah disepakati Bersama oleh kedua belah pihak (Safriliana et al., 2018).

Kedua belah pihak memiliki kepentingan yang berbeda, dimana principal berfokus pada peningkatan laba sedangkan agent tidak hanya berfokus pada peningkatan laba tetapi pada peningkatan bisnis perusahaan secara keseluruhan (Mohammed \& Muhammed, 2017). Perbedaan kepentingan tersebut dapat memicu konflik kepentingan antara agent dan principal yang dapat menimbulkan adanya agency cost (Annisya et al., 2016).

\section{Intellectual Capital}

Menurut Roos \& Pike (2018:17) Intellectual Capital merupakan seluruh sumber daya tidak berwujud yang berkontribusi pada penciptaan nilai tambah bagi perusahaan. Chowdhury et al. (2019) menyatakan bahwa intellectual capital tidak hanya sebagai penggerak dan sumber daya yang penting dalam penciptaan nilai tambah dan perkembangan perusahaan yang berkelanjutan tetapi juga sebagai sumber inovasi dan kunci pertumbuhan laba.

Intellectual capital adalah salah satu pendektaan yang digunakan dalam penilaian dan pengukuran aset tidak berwujud (Soewarno \& Tjahjadi, 2020). Intellectual capital diukur dengan $\mathrm{VAIC}^{\mathrm{TM}}$ (Value Added Intellectual Capital Coefficient). VAIC $^{\mathrm{TM}}$ dikembangkan oleh Pulic sebagai instrumen untuk mengukur kinerja intellectual capital sebuah perusahaan. Terdapat tiga unsur komponen pada VAIC $^{\mathrm{TM}}$ yaitu VACA (capital employed), VAHU (human capital), dan STVA (structural capital) (Sayyidah \& Saifi, 2017). Secara ringkas formulasi dan tahapan perhitungan VAIC $^{\mathrm{TM}}$ adalah sebagai berikut (Ulum, 2017): 
a. Menghitung Value Added (VA)

$$
\text { VA = OUT - IN }
$$

Sumber: Pulic dalam Ulum (2017)

Keterangan: : $\quad$ Value

Added

OUT (Output) : Total

penjualan dan pendapatan lain IN (Input) : Total seluruh beban yang dikorbankan untuk memperoleh pendapatan, kecuali beban karyawan

b. Menghitung Value Added Capital Employed (VACA)

VACA adalah indikator untuk value adde (VA) yang diciptakan oleh satu unit dari physical capital atau capital employed. Rasio ini menunjukkan kontribusi yang dibuat oleh setiap unit capital employed (CE) terhadap value added (VA) perusahaan.

VACA $=$ VA/CE

Sumber: Pulic dalam Ulum (2017)

Keterangan:

VACA : $\quad$ Value Added Capital Employed. Rasio VA terhadap CE

VA : Value Added

CE : Capital Employed. Dana yang tersedia atau jumlah ekuitas dan laba bersih

c. Menghitung Value Added Human Capital (VAHU)
VAHU menunjukkan berapa banyak value added (VA) dapat dihasilkan dengan dana yang dikeluarkan dengan tenaga kerja. Rasio ini menunjukkan kontribusi yang dibuat oleh setiap rupiah yang diinvestasikan untuk human capital (HC) terhadap value added (VA) perusahaan.

$$
\text { VAHU }=\mathbf{V A} / \mathbf{H C}
$$

Sumber: Pulic dalam Ulum (2017)

Keterangan:

VAHU : Value Added Human Capital. Rasio VA terhadap $\mathrm{HC}$

VA : Value Added

HC : Human Capital. Beban tenaga kerja (total gaji, upah dan pendapatan karyawan)

d. Menghitung Structural Capital Value Added (STVA)

Rasio ini mengukur jumlah SC yang dibutuhkan untuk menghasilkan value added (VA) dan merupakan indikasi bagaimana keberhasilan SC dalam penciptaan nilai.

STVA $=$ SC/VA

Sumber: Pulic dalam Ulum (2017)

Keterangan:

STVA : Structural Capital Value Added. Rasio SC terhadap VA

SC : Structural Capital (VA - HC)

VA : Value Added

e. Menghitung Value Added Intellectual Coefficient $\left(\mathrm{VAIC}^{\mathrm{TM}}\right)$ 


VAIC $^{\mathrm{TM}}=$ VACA + VAHU
+ STVA
Sumber: Pulic dalam Ulum
(2017)
Keterangan:
VAICTM $\quad$ Value
Added Intellectual Coefficient
VACA $\quad$ Value
Added Capital Employed
VAHU $\quad$ Value
Added Human Capital
STVA $\quad$ Structural
Capital Value Added

\section{Corporate Governance}

Menurut Forum for Corporate Governance in Indonesia (FCGI) Corporate Governance merupakan suatu seperangkat peraturan yang mengatur hubungan antara pemegang saham, pengurus atau pengelola perusahaan, pihak kreditur, pemerintah, karyawan serta para pemegang kepentingan internal dan eksternal yang berkaitan dengan hak - hak dan kewajiban atau dengan kata lain suatu sistem yang mengatur dan mengendalikan perusahaan dengan tujuan untuk menciptakan nilai tambah bagi semua pihak yang berkepentingan atau stakeholders (Hadyarti \& Mahsin, 2020). Corporate Governance adalah cara manajemen perusahaan bertanggung jawab kepada para pemegang saham (I. Putri \& Iramani, 2017). Dalam penelitian ini corporate governance diproksikan dengan menggunakan peringkat nilai komposit dari hasil self-assessment good corporate governance yang dilakukan perusahaan perbankan dalam mengukur kualitas penerapan corporate governance. Berdasarkan Surat Edaran Otoritas Jasa Keuangan SEOJK No. 13/SEOJK.03/2017, dalam rangka memastikan penerapan 5 (lima) prinsip dasar Tata Kelola yang baik, Bank harus melakukan penilaian sendiri (self-assessment) secara berkala yang paling sedikit meliputi 11 (sebelas) faktor penilaian penerapan Tata Kelola (D. A. Putri \& Yuliandhari, 2020).

Tabel 1 Peringkat Nilai Komposit SelfAssessment GCG

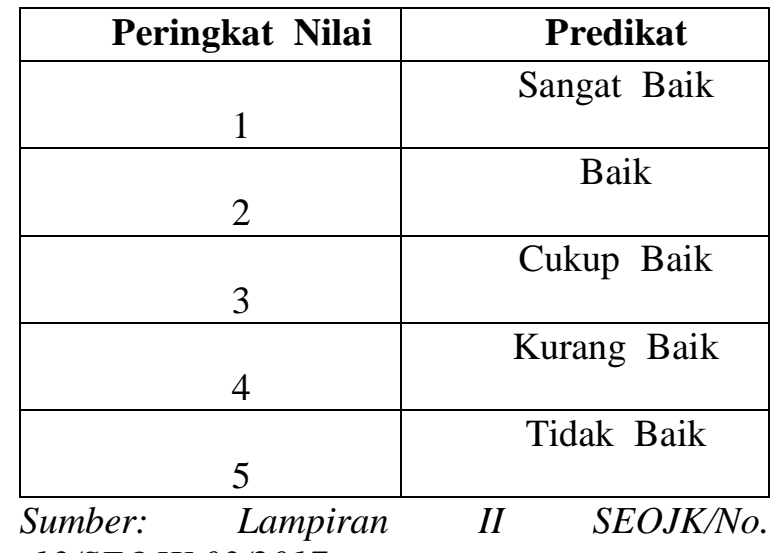

13/SEOJK.03/2017

Bank melalukan penilaian sendiri (self-assessment) good corporate governance dengan predikat peringkat 1 sampai dengan 5. Urutan peringkat GCG yang lebih baik yaitu jika angka yang didapat besar maka penerapan GCG tidak baik, sebaliknya jika angka peringkat yang didapat kecil maka penerapan GCG semakin baik.

\section{Nilai Perusahaan}

Manajer perusahaan dalam membuat keputusan mengenai kegiatan operasional perusahaan selalu bertujuan untuk memaksimalkan nilai perusahaan (Sukoco, 2020). Menurut Sartono (2010:487) nilai perusahaan merupakan nilai jual sebuah perusahaan sebagai entitas bisnis yang sedang beroperasi. Nilai perusahaan adalah suatu tujuan jangka panjang perusahaan yang dilihat dari harga per sahamnya karena merupakan suatu penilaian investor terhadap perusahaan yang dapat diamati melalui pergerakan harga saham perusahaan yang ditransaksikan di bursa untuk perusahaan yang sudah go public (Sulastri \& Nurdiansyah, 2017). 
Dalam penelitian ini nilai perusahaan diukur menggunakan indikator Tobin's $Q$. Metode Tobin's $Q$ dikembangkan oleh James Tobin dan menggunakan ukuran Q ratio (Nurhayati, 2017). Tobin's $Q$ diformulasikan sebagai berikut:

$$
\text { Tobin's } Q=\frac{M E+D E B T}{T A}
$$

Sumber: (Nurhayati, 2017)

\section{Profitabilitas}

Profitabilitas merupakan salah satu pengukuran kinerja perusahaan yang menunjukkan kemampuan suatu perusahaan dalam memperoleh laba selama periode tertentu pada tingkat penjualan, aset dan ekuitas saham tertentu (Priatna, 2016). Profitabilitas mencerminkan kondisi keuangan perusahaan dan alat ukur kesuksesan manajer dalam mengelola perusahaan (Kherismawati et al., 2017).

Rasio profitabilitas perusahaan adalah rasio yang diukur berdasarkan perbandingan antara laba setelah pajak dengan total aset perusahaan. Salah satu rasio profitabilitas adalah Return on Assets (ROA). Return on Assets (ROA) adalah indikator keberhasilan perusahaan dalam memperoleh laba bersih dari jumlah dana yang diinvestasikan atau total aset perusahaan (Sayyidah \& Saifi, 2017). Pengukuran rasio Return on Assets (ROA sebagai berikut:

$$
\text { ROA }=\frac{E A T}{\text { Total Assets }}
$$

Sumber: (Sayyidah \& Saifi, 2017)

\section{METODE PENELITIAN}

$$
\begin{aligned}
& \text { Metode penelitian yang digunakan } \\
& \text { dalam penelitian ini adalah metode } \\
& \text { kuantitatif. Metode ini disebut metode } \\
& \text { kuantitatif karena data penelitian berupa } \\
& \text { angka - angka dan analisis menggunakan } \\
& \text { statistik (Sugiyono, 2019:15). Objek dalam } \\
& \text { penelitian ini adalah intellectual capital } \\
& \left(\mathrm{X}_{1}\right) \text {, corporate governance }\left(\mathrm{X}_{2}\right) \text {, nilai }
\end{aligned}
$$

perusahaan (Y) dan profitabilitas (Z). Populasi dan subjek yang digunakan dalam penelitian ini adalah seluruh perusahaan sub sektor perbankan yang terdaftar di Bursa Efek Indonesia (BEI) selama tahun 2015 - 2019 dengan jumlah 45 perusahaan. Penentuan sampel pada penelitian ini menggunakan teknik purposive sampling.

Teknik purposive sampling merupakan salah satu teknik pengambilan sampel dengan pertimbangan atau kriteria tertentu (Sugiyono, 2019:138). Kriteria pemilihan sampel pada penelitian ini adalah sebagai berikut: 1). Perusahaan sub sektor perbankan yang terdaftar di Bursa Efek Indonesia selama periode 2015 - 2019, 2). Perusahaan sub sektor perbankan yang listing di Bursa Efek Indonesia sebelum tahun 2015, 3). Perusahaan sub sektor perbankan yang masuk dalam kategori papan utama, 4). Perusahaan sub sektor perbankan yang mempublikasikan laporan tahunan (annual report) secara berturut turut selama periode 2015 - 2019, 5). Perusahaan sub sektor perbankan yang melengkapi laporan GCG dengan informasi terkait hasil Self-Assessment GCG selama periode 2015 - 2019, 6). Perusahaan sub sektor perbankan yang tidak mengalami kerugian selama periode 2015 - 2019, 7). Perusahaan sub sektor perbankan yang memiliki informasi lengkap terkait variabel penelitian ini. Dari hasil pengambilan sampel penelitian maka didapatkan 75 sampel penelitian.

Jenis data dalam penelitian ini adalah data sekunder berupa laporan tahunan (annual report) dan laporan GCG perusahaan sub sektor perbankan. Sumber data berasal dari website resmi Bursa Efek Indonesia (www.idx.co.id) dan website resmi masing - masing perusahaan perbankan. Metode pengumpulan data yang digunakan dalam penelitian ini adalah studi kepustakaan dan dokumentasi. Teknik analisis data yang digunakan dalam penelitian ini adalah Structural Equation 
Modelling - Partial Least Squares (SEMPLS) dengan software WarpPLS 7.0. Analisis data terdiri dari analisis statistik deskriptif, outer model evaluation of reflective indicator, outer model evaluation of formative construct, inner model evaluation dan uji hipotesis.

Penelitian ini menggunakan tiga jenis variabel untuk menguji hipotesis yang diajukan. Variabel tersebut yaitu variabel independen, variabel dependen, dan variabel moderasi. Variabel independen dalam penelitian ini adalah Intellectual Capital dan Corporate Governance. Indikator pengukuran Intellectual Capital menggunakan Value Added Intellectual Coefficient $\quad\left(\mathrm{VAIC}^{\mathrm{TM}}\right.$ ) dan indikator pengukuran Corporate Governance menggunakan hasil penilaian SelfAssessment GCG Perusahaan Perbankan. Variabel dependen dalam penelitian ini adalah Nilai Perusahaan dengan menggunakan indikator pengukuran yaitu Tobin's $Q$. Peneliti menggunakan profitabilitas sebagai variabel moderasi dengan indikator pengukuran yaitu Return on Assets (ROA).

\section{HASIL DAN PEMBAHASAN}

Teknik analisis data dalam penelitian ini yaitu metode Structural Equation Modeling-Partial Least Square (SEMPLS) dengan menggunakan software WarpPLS 7.0. Persamaan Struktural: TOBINS_Q $=0,279($ VAIC) $+0,033(\mathrm{CG})$ $+0,522(\mathrm{ROA} * \mathrm{VAIC})-0,183\left(\mathrm{ROA}^{*} \mathrm{CG}\right)$

Tabel 2 Nilai R Square

\begin{tabular}{|c|c|c|c|c|c|c|}
\hline & VAIC & CG & ROA & TOBINS $Q$ & ROA*VAC & $\mathrm{ROA}^{*} \mathrm{CG}$ \\
\hline R-squared & & & & 0.351 & & \\
\hline Adi, R-sguared & & & & 0.314 & & \\
\hline
\end{tabular}

Nilai $\mathrm{R}^{2}$ variabel Tobins'Q sebesar 0,351 artinya variabel Tobins'Q dapat dijelaskan oleh variabel VAIC, CG, ROA*VAIC dan ROA*CG sebesar $35,1 \%$
Tabel 3 Uji Kecocokan Model

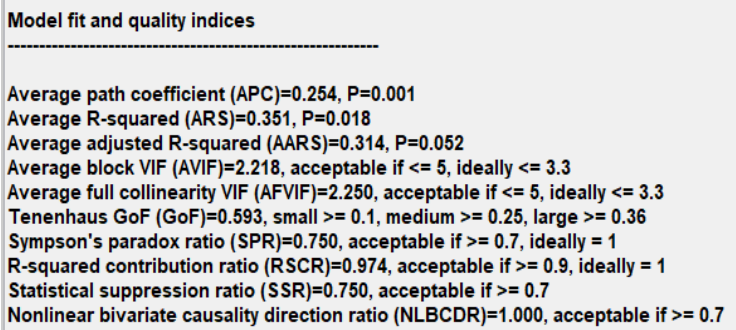

Tabel 5

Hasil Analisis Uji Kecocokan Model

\begin{tabular}{|c|c|c|c|}
\hline Kriteria & Hasil Analisis & Syarat & Keterangan \\
\hline $\mathrm{APC}$ & $\begin{array}{c}\mathrm{APC}=0,254 \\
\mathrm{P}=0,001\end{array}$ & $\mathrm{P} \leq 0,05$ & Diterima \\
\hline ARS & $\begin{array}{c}\mathrm{ARS}=0,351 \\
\mathrm{P}=0,018\end{array}$ & $\mathrm{P} \leq 0,05$ & Diterima \\
\hline AARS & $\begin{array}{c}\text { AARS }= \\
0,314, \mathrm{P}= \\
0,052\end{array}$ & $\mathrm{P} \leq 0,05$ & $\begin{array}{l}\text { Kurang } \\
\text { Baik }\end{array}$ \\
\hline AVIF & 2,218 & $\begin{array}{c}\text { Diterima } \\
\text { jika } \leq \\
5, \\
\text { idealnya } \\
\leq 3\end{array}$ & Ideal \\
\hline AFVIF & 2,250 & $\begin{array}{c}\text { Diterima } \\
\text { jika } \leq \\
5, \\
\text { idealnya } \\
\leq 3\end{array}$ & Ideal \\
\hline GOF & 0,593 & $\begin{array}{c}\text { Kecil } \geq \\
0,1, \\
\text { Medium } \\
\geq 0,25 \\
\text { Kuat } \geq \\
0,36\end{array}$ & $\begin{array}{l}\text { Model } \\
\text { kuat }\end{array}$ \\
\hline SPR & 0,750 & $\begin{array}{c}\text { Diterima } \\
\text { jika } \geq \\
0,7, \\
\text { idealnya } \\
=1\end{array}$ & Diterima \\
\hline RSCR & 0,974 & $\begin{array}{c}\text { Diterima } \\
\text { jika } \geq \\
0,9, \\
\text { idealnya } \\
=1\end{array}$ & Diterima \\
\hline
\end{tabular}




\begin{tabular}{|l|c|c|l|}
\hline SSR & 0,750 & $\begin{array}{c}\text { Diterima } \\
\text { jika } \geq \\
0,7\end{array}$ & Diterima \\
\hline NLBCDR & 1,000 & $\begin{array}{c}\text { Diterima } \\
\text { jika } \geq \\
\end{array}$ & Diterima \\
& & 0,7 & \\
\hline
\end{tabular}

Sumber: Data diolah penulis

Pada tabel Model Fit dan Quality Indices menunjukkan bahwa hasil dalam penelitian ini telah memenuhi kriteria uji kecocokan sehingga modelnya sudah terpenuhi.

Gambar 1

Analisis Jalur

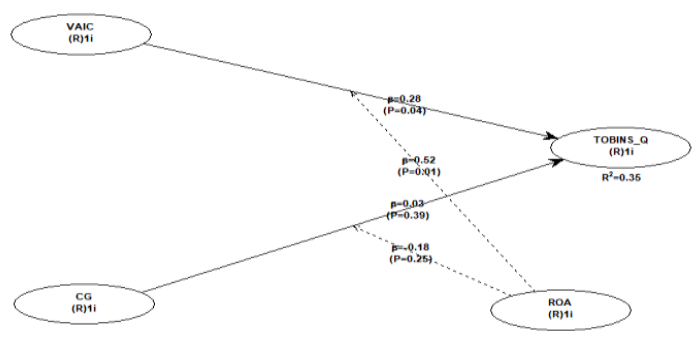

Tabel 5

Uji Hipotesis

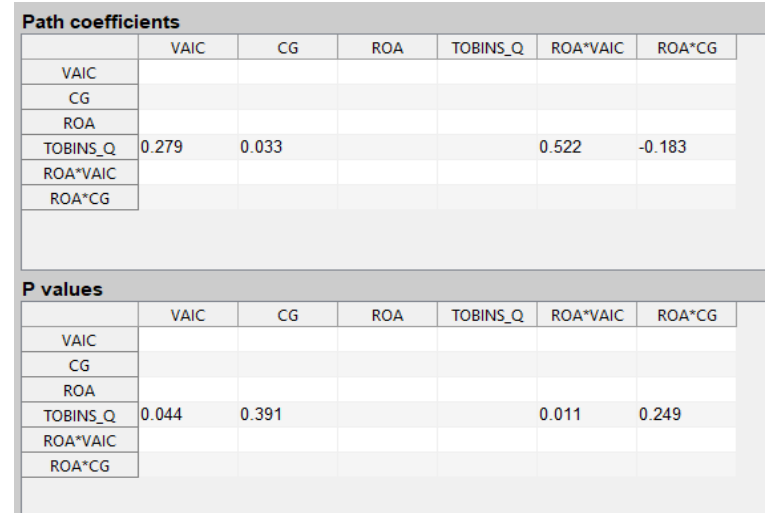

Sumber: Data diolah penulis
Berikut merupakan penjelasan hasil pada tabel:

1. Pengaruh antara $X_{1}$ (VAIC) berpengaruh positif dan signifikan terhadap $\mathrm{Y}$ (TOBINS'Q) karena nilai $p$-values sebesar 0,044 dimana lebih kecil dari 0,05 . Nilai path coefficients sebesar 0,279 menunjukkan arah pengaruhnya positif.

2. Pengaruh antara $X_{2} \quad(C G)$ tidak berpengaruh signifikan terhadap $\mathrm{Y}$ (TOBINS'Q) karena nilai p-values sebesar 0,391 dimana lebih besar dari 0,05 .

3. ROA memoderasi pengaruh $\mathrm{X}_{1}$ (VAIC) terhadap Y (TOBINS'Q) karena nilai $p$ values sebesar 0,011 dimana lebih kecil dari 0,05. Nilai path coefficients sebesar 0,522 menunjukkan efek moderasinya memperkuat hubungan $\mathrm{X}_{1}$ (VAIC) dan $\mathrm{Y}$ (TOBINS'Q).

4. ROA tidak memoderasi pengaruh $\mathrm{X}_{2}$ (CG) terhadap Y (TOBINS'Q) karena nilai $p$ values sebesar 0,249 dimana lebih besar dari 0,05 .

5 .

\section{KESIMPULAN}

Berdasarkan analisa dan pengujian yang telah diteliti oleh peneliti, dapat ditarik kesimpulan bahwa intellectual capital berpengaruh positif dan signifikan terhadap nilai perusahaan yang berarti apabila perusahaan memiliki nilai intellectual capital yang tinggi maka perusahaan memiliki keunggulan kompetitif yang mampu mengatasi ketatnya persaingan bisnis sehingga nilai perusahaan semakin meningkat. Corporate Governance tidak berpengaruh terhadap nilai perusahaan. Profitabilitas yang diproksikan dengan ROA dapat memoderasi pengaruh intellectual capital terhadap nilai perusahaan. Profitabilitas yang diproksikan dengan ROA tidak dapat memoderasi pengaruh corporate governance terhadap nilai perusahaan. 


\section{REFERENSI}

[1] W. S. Nugroho and G. Gudono, "The Significance Key of Intellectual Capital To Increase Financial Performance, Firm's Growth, and Market Value," Indones. J. Account. Res., vol. 21, no. 2, pp. 269-290, 2018, doi: 10.33312/ijar.361.

[2] N. Soewarno and B. Tjahjadi, "Measures That Matter: An Empirical Investigation of Intellectual Capital and Financial Performance of Banking Firms in Indonesia," J. Intellect. Cap., vol. 21, no. 6, pp. 1085-1106, 2020, doi: 10.1108/JIC-09-2019-0225.

[3] M. A. Fardiansyah and F. A. Faisal, "Faktor - Faktor Nilai Perusahaan: Kajian Berdasarkan Modal Intelektual, Pertumbuhan dan Kinerja Perusahaan," E-Jurnal Akunt., vol. 30, no. 4, pp. 911921, 2020.

[4] U. Sayyidah and M. Saifi, "Pengaruh Intellectual Capital Terhadap Nilai Perusahaan dengan Profitabilitas Sebagai Variabel Moderasi," J. Adm. Bisnis, vol. 46, no. 1, pp. 163-171, 2017.

[5] L. F. Yulandari and H. Gunawan, "Pengaruh Intellectual Capital Terhadap Nilai Pasar Dan Kinerja Keuangan Perusahaan Yang Terdaftar Di Bursa Efek Indonesia," J. Appl. Manag. Account., vol. 3, no. 1, pp. 36-50, 2019, doi: 10.30871/jama.v3i1.938.

[6] Suhadak, Kurniaty, S. R. Handayani, and S. M. Rahayu, "Stock Return and Financial Performance as Moderation Variable in Influence of Good Corporate Governance Towards Corporate Value," Asian J. Account. Res., vol. 4, no. 1, pp. 18-34, 2019, doi: 10.1108/ajar-07-20180021.

[7] N. E. Rochmawati, Tarjo, and S. Musyarofah, "The Implementation of Good Corporate Governance and Efforts To Prevent Fraud in Banking Companies," J. Reviu Akunt. dan
Keuang., vol. 10, no. 1, pp. 136-149, 2020, doi: 10.22219/jrak.v10i1.10268.

[8] Y. Arifardhani, Hukum Pasar Modal Di Indonesia: Dalam Perkembangan, 1st ed. Jakarta: Kencana, 2020.

[9] S. A. Purnama and B. Rikumahu, "Analisis Faktor Yang Mempengaruhi Harga Saham Menggunakan Metode Principal Component Analysis (Studi pada Sub Sektor Perbankan Saham LQ45 yang terdaftar di Bursa Efek Indonesia Periode 2015 - 2019)," e-Proceeding Manag., vol. 7, no. 2, p. 5240, 2020.

[10] J. Barney, "Firm Resources and Sustained Competitive Advantage," J. Manage., vol. 17, no. 1, 1991.

[11] I. Ulum, Intellectual Capital Model Pengukuran, Framework Pengungkapan dan Kinerja Organisasi. Malang: UMM Press, 2017.

[12] P. J. Davis and E. Simpson, "ResourceBased Theory, Competition and Staff Differentiation in Africa: Leveraging Employees as A Source of Sustained Competitive Advantage," Am. J. Manag., vol. 17, no. 1, p. 19, 2017.

[13] D. A. D. Lestari and M. D. Satyawan, "Pengaruh Intellectual Capital Terhadap Nilai Perusahaan Dengan Profitabilitas Sebagai Variabel Moderasi," J. Akunt. AKUNESA, vol. 7, no. 1, pp. 1-22, 2019.

[14] M. Spence, "Job Market Signaling," Q. J. Econ., vol. 87, no. 3, pp. 355-374, 1973, doi: $10.2307 / 1882010$.

[15] B. S. Hidayati and E. D. Retnani, "Pengaruh Struktur Modal, Good Corporate Governance dan Ukuran Perusahaan terhadap Nilai Perusahaan," J. Ilmu dan Ris. Akunt., vol. 9, no. 6, pp. $1-18,2020$.

[16] C. Deegan, Financial Accounting Theory. Sydney: McGraw-Hill Book Company, 2004.

[17] S. Devi, "Pengaruh Pengungkapan Enterprise Risk Management Dan Pengungkapan Intellectual Capital Terhadap Nilai Perusahaan," J. Akunt. dan Keuang. Indones., vol. 14, no. 1, pp. 
20-45, 2017.

[18] M. C. Jensen and W. H. Meckling, "Theory of The Firm: Managerial Behavior, Agency Costs and Ownership Structure," J. financ. econ., vol. 3, pp. 305-360, 1976.

[19] R. Safriliana, B. Subroto, I. Subekti, and A. Fuad Rahman, "An Overview on Contracting Theory and Agency Theory: Determinants of Voluntary Public Accounting Firms Switching," KnE Soc. Sci., vol. 3, no. 10, pp. 292-302, 2018, doi: $10.18502 / \mathrm{kss} . v 3 i 10.3381$.

[20] S. A. S. A.-N. Mohammed and J. Muhammed, "The Relationship Between Agency Theory, Stakeholder Theory and Shariah Supervisory Board in Islamic Banking: An Attempt Towards Discussion," Huanomics, vol. 33, no. 1, pp. 75-83, 2017, doi: https:/doi.org/10.1108/H-08-2016-0062.

[21] M. Annisya, Lindrianasari, and Y. Asmaranti, "Pendeteksian Kecurangan Laporan Keuangan Menggunakan Fraud Diamond," J. Bisnis dan Ekon., vol. 23, no. 1, pp. 72-89, 2016.

[22] G. Roos and S. Pike, Intellectual Capital as a Management Tool. United Kingdom: Routledge, 2018.

[23] L. A. M. Chowdhury, T. Rana, and M. I. Azim, "Intellectual Capital Efficiency and Organisational Performance in the Context of The Pharmaceutical Industry in Bangladesh," J. Intellect. Cap., vol. 20, no. 6, pp. 784-806, 2019, doi: 10.1108/JIC-10-2018-0171.

[24] V. Hadyarti and T. M. Mahsin, "Corporate Social Responsibility (CSR) Dan Good Corporate Governance (GCG) Sebagai Indikator Dalam Menilai Nilai Perusahaan," Competence J. Manag. Stud., vol. 13, no. 1, pp. 17-33, 2020, doi: 10.21107/kompetensi.v13i1.6819.

[25] I. Putri and R. Iramani, "Studi Good Corporate Governance dan Kinerja Saham Perusahaan Publik pada Sektor Manufaktur di Indonesia," J. Bus. Bank., vol. 7, no. 2, pp. 177-192, 2017, doi: 10.14414/jbb.v7i2.990.

[26] D. A. Putri and W. S. Yuliandhari, "Pengaruh Tingkat Kesehatan Keuangan Bank Menggunakan RGEC Terhadap Pertumbuhan Laba," J. Akunt. Bisnis dan Ekon., vol. 6, no. 1, pp. 1569-1576, 2020.

[27] Y. D. Sukoco, "Penerapan Good Corporate Governance di Perusahan Keuangan dan Pengaruhnya Terhadap Nilai Perusahaan Menggunakan Kinerja Keuangan Sebagai Variabel Perantara (Studi Empiris pada Perusahaan Keuangan Periode 2017-2018)," J. Ilm. Mhs. Ekon., vol. 03, no. 02, pp. 232-246, 2020.

[28] A. Sartono, Manajemen Keuangan Teori dan Aplikasi. Yogyakarta: BPFE, 2010.

[29] E. M. Sulastri and D. H. Nurdiansyah, "Pengaruh Good Corporate Governance Terhadap Kinerja dan Nilai Perusahaan (Studi Pada Perusahaan Yang Terindeks Oleh CGPI)," J. Manajerial, vol. 2, no. 2, pp. 35-45, 2017.

[30] S. Nurhayati, "Analisa Pengaruh Intellectual Capital Terhadap Kinerja Pasar Dan Kinerja Keuangan Pada Perusahaan LQ45 Yang Terdaftar Di Bursa Efek Indonesia Periode Tahun 2010-2013," J. ASET (Akuntansi Riset), vol. 9, no. 1, pp. 133-172, 2017, doi: 10.17509/jaset.v9i1.5260.

[31] H. Priatna, "Pengukuran Kinerja Perusahaan Dengan Rasio Profitabilitas," AKURAT J. Ilm. Akunt., vol. 7, no. 2, pp. 44-53, 2016.

[32] N. P. E. Kherismawati, N. L. P. Wiagustini, and M. P. Dewi, "Profitabilitas dan Leverage Sebagai Prediktor Kebijakan Dividen dan Nilai Perusahaan (Studi Pada Perusahaan Manufaktur di Bursa Efek Indonesia)," JAGADHITA J. Ekon. dan Bisnis, vol. 3, no. 1, pp. 94-108, 2017.

[33] Sugiyono, Metode Penelitian Kuantitatif. Bandung: Alfabeta, 2019. 